$$
\text { MT-DP - 2013/22 }
$$

Corporate financing under moral hazard and the

\author{
default risk of buyers
}

PÉTER CSÓKA

DÁNIEL HAVRAN

NÓRA SZÜCS 
Discussion papers

MT-DP - 2013/22

Institute of Economics, Centre for Economic and Regional Studies, Hungarian Academy of Sciences

KTI/IE Discussion Papers are circulated to promote discussion and provoque comments. Any references to discussion papers should clearly state that the paper is preliminary. Materials published in this series may subject to further publication.

Corporate financing under moral hazard and the default risk of buyers

Authors:

Péter Csóka research fellow Institute of Economics

Centre for Economic and Regional Studies

Hungarian Academy of Sciences

E-mail: csoka.peter@krtk.mta.hu

Dániel Havran

Corvinus University of Budapest

Department of Finance

E-mail: daniel.havran@uni-corvinus.hu

Nóra Szűcs

Corvinus University of Budapest

Department of Finance

E-mail:nora.szucs@uni-corvinus.hu

July 2013

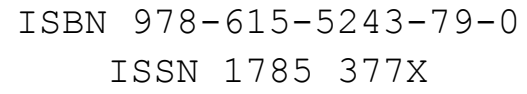




\title{
Corporate financing under moral hazard and the default risk of buyers
}

\author{
Péter Csóka - Dániel Havran - Nóra Szűcs
}

\begin{abstract}
We extend the theoretical model of external corporate financing to the case when the buyers of the borrowing firm may default during the financing period. In our setup there is an asymmetric information and hence moral hazard between the lender and the borrower concerning the effrts of the borrower. We define the optimal debt contract in two cases. In the symmetric case the lender and the borrower has the same information about the buyer, its probability of default. In the asymmetric case the borrower learns whether the buyer will pay or not before choosing her level of efforts. We prove that in the asymmetric case the borrowing capacity and the welfare of the society is weakly smaller than in the symmetric case. We also show that the nonnegative default risk of a buyer weakly decreases borrowing capacity compared to the case when the buyer pays for sure. However, it turns out that having a risky buyer might increase borrowing capacity and welfare.
\end{abstract}

Keywords: game theory, moral hazard, corporate financing, trade credit

JEL classification: G32, C72

Acknowledgements:

This work was partially supported by the European Union and the European Social Fund through project FuturICT.hu (grant no.: TAMOP-4.2.2.C-11/1/KONV-2012-0013). 


\title{
Vállalatfinanszírozás morális kockázat és nem fizető vevő esetén
}

\author{
Csóka Péter - Havran Dániel - Szűcs Nóra
}

\section{Összefoglaló}

\begin{abstract}
A tanulmányban a külső vállalatfinanszírozás elméleti modelljét terjesztjük ki arra az esetre, amelyben a finanszírozási periódus alatt a hitelfelvevő vállalat vevői nem fizethetnek. Modellünkben aszimmetrikus információ és így morális kockázat van a hitelnyújtó és a hitelfelvevő között a hitelfelvevő erőfeszítésére vonatkozóan. Az optimális hitelszerződést két esetben definiáljuk. A szimmetrikus esetben a hitelnyújtó és a hitelfelvevő ugyanazzal az információval rendelkezik a vevőről, ismerik annak nemfizetési valószínűségét. Az aszimmetrikus esetben a hitelfelvevő még azelőtt megtudja, hogy fizet-e a vevője, mielőtt megválasztaná erőfeszítési szintjét. Megmutatjuk, hogy az aszimmetrikus esetben a felvehető hitel mennyisége és a társadalmi jólét (gyengén) kisebb, mint a szimmetrikus esetben. Azt is megmutatjuk, hogy a vevő nemfizetési kockázata (gyengén) csökkenti a felvehető hitel nagyságát ahhoz viszonyítva, amikor a vevő biztosan fizet. Ugyanakkor előfordulhat, hogy a nem fizető vevők arányának növelése növelheti a felvehető hitel nagyságát és a jólétet.
\end{abstract}

Tárgyszavak: játékelmélet, morális kockázat, vállalati finanszírozást, kereskedelmi hitel

JEL kód: G32, C72 


\title{
Corporate financing under moral hazard and the default risk of buyers
}

\author{
Péter Csóka* Dániel Havran ${ }^{\dagger} \quad$ Nóra Szücs ${ }^{\ddagger}$
}

June 23, 2013

\begin{abstract}
We extend the theoretical model of external corporate financing to the case when the buyers of the borrowing firm may default during the financing period. In our setup there is an asymmetric information and hence moral hazard between the lender and the borrower concerning the efforts of the borrower. We define the optimal debt contract in two cases. In the symmetric case the lender and the borrower has the same information about the buyer, its probability of default. In the asymmetric case the borrower learns whether the buyer will pay or not before choosing her level of efforts. We prove that in the asymmetric case the borrowing capacity and the welfare of the society is weakly smaller than in the symmetric case. We also show that the nonnegative default risk of a buyer weakly decreases borrowing capacity compared to the case when the buyer pays for sure. However, it turns out that having a risky buyer might increase borrowing capacity and welfare.
\end{abstract}

Keywords: game theory, moral hazard, corporate financing, trade credit JEL classification G32, C72

\section{Introduction}

In vertically integrated industries, where suppliers dominantly depend on their buyers, the default of a buyer may easily result financial contagion in the whole supply chain.

\footnotetext{
*Corvinus University of Budapest, Department of Finance and "Momentum" Game Theory Research Group (LD-004/2010) Centre for Economic and Regional Sciences, Hungarian Academy of Sciences. Email: peter.csoka@uni-corvinus.hu. This work was partially supported by the European Union and the European Social Fund through project FuturICT.hu (grant no.: TAMOP-4.2.2.C-11/1/KONV-2012-0013).

${ }^{\dagger}$ Corvinus University of Budapest, Department of Finance. E-mail: daniel.havran@uni-corvinus.hu.

${ }^{\ddagger}$ Corvinus University of Budapest, Department of Finance. E-mail: nora.szucs@uni-corvinus.hu.
} 
Several authors emphasize the risk of financial contagion in supply chains. Raddatz (2010) tested and confirmed the hypothesis whether trade credit chains strengthen comovements of different sectors as well. Beck, Demirguc-Kunt, and Peria (2007) verifies the well-known phenomenon that typically Small and Medium Size Enterprises (SMEs) do not pay on scheduled time. According to the report of Klingen and Castillo (2012), the number of non-performing loans have increased very rapidly in general after the crisis in Central, Eastern and Southeast Europe.

We model the loan contracting of a firm which is facing counterparty risk from its buyers. According to the study of Beck, Demirguc-Kunt, and Peria (2007), the share of bank loans compared to the total assets of firms was $17.93 \%$ in developed, and $22.93 \%$ in developing economies. They remark that both secured and unsecured lending played an important role. We concentrate on unsecured lending and on the role of information about the efforts of the borrowing firm and its buyers. Several country studies have analyzed the financial relationships within supply chains in developed and developing countries recently. Garcia-Appendini and Montoriol-Garriga (2012) note that US firms provided liquidity to each other during the crisis in 2007-2008. Demirguc-Kunt and Maksimovic (2001) emphasize that information about the buyers of a firm is potentially valuable. Moreover, they show that suppliers provide credit for them especially where banks do not reach reliable information on buyers because of the lack of transparency. Some other authors have suggested that this information advantage in the funding of firms may imply a complementarity between trade credit and bank loans: financing of buyers can even strengthen the bank lending activity (see Cook (1999) in a Russian study or Garcia-Appendini (2007)). Carbó-Valverde, Rodríguez-Fernández, and Udell (2008) also confirm that trade credits are given more often in an opaque environment. The above cited papers consistently state that this kind of credit appears when the supplier has more information on a reliable buyer than the bank of the buyer. The question is how a bank should finance this supplier.

We choose our approach from the wide family of debt contracting analytical frameworks introduced by Fudenberg and Tirole (1990), Hart and Moore (1998), Tirole (2006) and others. While the above mentioned studies consider the economic representation of contracting in general, there are more specific papers related to the role of trade credit in debt contracts. One can find the original theoretical explanations on the rationale of trade credit in Schwartz (1974), Myers (1977), Emery (1984) and Biais and Gollier (1997). Brennan et al (1988) as well as Petersen and Rajan (1994) theoretically derive that trade credit can be used as a tool for price discrimination, or for guaranteeing higher product quality. Among others, Devjak and Bogataj (2007) investigate the mathematical modelling of cash and liquidity issues by firms. Our main theoretical base is the seminal article of Holmstrom and Tirole (2000) who analyze firm liquidity issues in debt contracts. 
This paper revises the borrower-lender relationship in case of trade credit. We provide a model of corporate financing where the lender has to consider the counterparty risk originated from the buyers of the borrower as well. In our setup there is an asymmetric information and hence moral hazard between the lender and the borrower concerning the efforts of the borrower. We define the optimal debt contract in two cases. According to the symmetric case neither the lender nor the borrower knows whether the buyer will pay or not in advance. In the asymmetric case the borrower learns the action of the buyer before the moral hazard, contracting is under additional asymmetric information. We show that in the asymmetric case the borrowing capacity and the welfare of the society is weakly smaller than in the symmetric case. We also prove that the nonnegative default risk of a buyer weakly decreases borrowing capacity compared to the case when the buyer pays for sure. However, it turns out that having a risky buyer might increase borrowing capacity and welfare.

The rest of the paper is structured as follows. Section 2 introduces the concept of bank-borrower-buyer interdependencies and our model in two different information setups. This section also presents and derives the optimal debt contracts. In Section 3 we prove and illustrate our results. The last section concludes.

\section{The model}

When modeling the bank loan constraints of a firm with a buyer who might default, we concentrate on the moral hazard aspects (what the firm will do with the loan) and assume away other considerations like risk averse lenders or lenders with market power. As we will see even in this setting we observe credit rationing.

The general setup of our model using the notation of Tirole (2006) is the following. A risk neutral entrepreneurial firm, where the owner manages the firm with limited liability, wishes to start an investment project of size $I \in[0, \infty)$ resulting in a risky payoff in some future point of time. When $I$ is invested in case of success the project yields payoff $R I$ (constant returns to scale), where $R>1$. In case of failure, the whole investment is lost. Assuming that the expected net present value of the project is positive, due to the constant returns to scale investment technology the firm would like to invest as much as possible. However, the initial cash asset of the firm is $A$, thus the firm is ready to borrow $I-A$ under reasonable conditions. We assume that lenders are also risk neutral, there is perfect competition among them and without loss of generality the expected rate of return is normalized to zero. Under those conditions the firm would like to borrow as much as possible, but moral hazard makes it difficult. The success of the project depends on how much effort the borrower invests into it. We assume two discrete levels of efforts. 
With higher efforts of the borrower the probability of success is $p_{H}$, with lower efforts it is $p_{L}$, where $0 \leq p_{L}<p_{H} \leq 1$. To denote the difference in those probabilities we will use $\Delta p=p_{H}-p_{L}$. We will also refer to higher efforts as behaving and to lower efforts as shirking. In case of shirking the borrower receives a private benefit proportional to the size of the project $B I$, where $B>0$. The shirking gain $B I$ can be considered as the utility of the efforts saved by shirking, or it can also be seen as using the assets of the firm in a way that only brings private benefits to her but creates no value for the lender.

The novelty in our model is that the borrower and the lender agree on the amount of the loan $I-A$ taking into account an exogenous third party, the buyer of the borrower. In case the buyer defaults, then part $c R I$ is lost from the payoff of an otherwise successful project, where the ratio of potential loss due to the buyer $c \in[0,1]$. In case of failure, due to the limited liability of the borrower the payoff of the project remains zero. The buyer of the borrower pays with probability $q \in[0,1]$ and defaults with probability $1-q$. The loss $c I$ can be interpreted as a defaulted trade credit or as the economic loss due to late payment. Moreover, if the buyer is not paying, then the probability of success $\left(p_{H}\right.$ or $\left.p_{L}\right)$ is multiplied by $\delta \in[0,1]$. The factor $\delta$ can be interpreted as a common macroeconomic factor or simply as the complication caused by the non-paying buyer.

The timeline of the project is illustrated in Figure 1. In theory we have four cases, both the borrower and the lender can learn the action of the buyer before or after the moral hazard. We investigate two alternatives. According to the symmetric case neither the lender nor the borrower has any information about the action of the buyer until its payment date. Thus both the lender and the borrower negatively modify their expectations about the payoff of the project due to the possible losses. One can identify this situation as the typical problem of buyer delivery risk, which may cause contagion of bankruptcies. In the asymmetric case the borrower learns the action of her buyer before the moral hazard, contracting is under additional asymmetric information. In this case as the borrower learns the solvency of the buyer much earlier than the lender, she can use this information to change her level of efforts. In an economy, where contagion of defaults is general, and banks cannot obtain the counterparty risk of borrowers related to their buyers, lenders also build this issue into their expectations. We exclude the other two alternatives on timing issues. When both the lender and the borrower know in advance the default of buyer, then there is not much to model. Finally, it is not common in practice that a lender gets informed before the borrower about the action of her buyer. Thus we will compare the symmetric case to the asymmetric one, where the borrower has information advantage on her buyer and can use it to decide whether to behave or shirk.

In both cases the expected net present value of the project is calculated as follows.

$$
E[\mathrm{NPV}]=p[q+(1-q) \delta(1-c)] R I-I=p \alpha R I-I,
$$




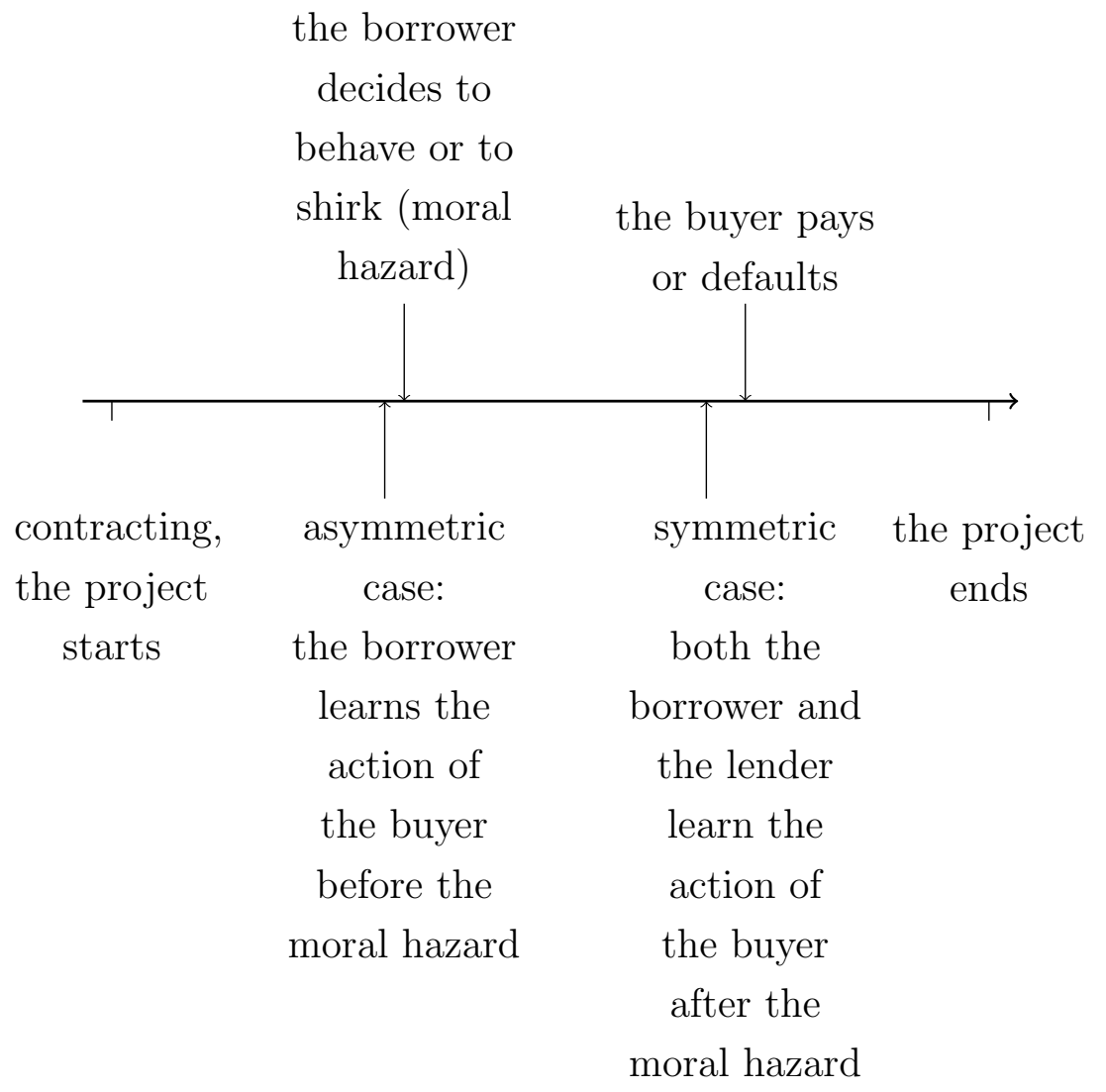

Figure 1: Timing.

where $p$ is the probability of success in general (it can be either $p_{H}$ or $p_{L}$ ) and $\alpha=$ $q+(1-q) \delta(1-c)$ can be interpreted as the expected discount to the payoff of the project $R I$ due to the default risk of the buyer.

Remember that both the borrower and the lender are risk neutral, hence their decisions are based upon expected value. We assume that the expected net present value of the project is positive only if the borrower behaves. It is negative even considering the expected private benefit of shirking, which is

$$
[q+(1-q)(1-c)] B I=\gamma B I,
$$

where $\gamma=q+(1-q)(1-c)$ is the expected reduction in the value of the private benefit of the project $B I$ due to the default risk of the buyer. We call the above assumption the moral hazard assumption and formalize it using Equations (2) and (1) as follows.

Assumption 2.1. (Moral hazard)

$$
\begin{aligned}
& E\left[\mathrm{NPV}_{\text {behaving }}\right]=p_{H} \alpha R I-I>0 \\
& E\left[\mathrm{NPV}_{\text {shirking }}\right]=p_{L} \alpha R I+\gamma B I-I<0,
\end{aligned}
$$


Due to Assumption 2.1 the lender should force the borrower to behave. The loan agreement is defined as follows. In case of success the borrower gets $R_{b}$ independently of the action of her buyer and the remaining payoff goes to the lender. In case of failure nobody gets anything from the payoff of the project, only shirking can give payoff to the borrower.

Finally, we assume that all the parameters of the model are common knowledge between the borrower and the lender.

\subsection{The symmetric case}

In this case neither the lender nor the borrower has any information about the action of the buyer until its payment date. Figure 2 gives an overview of the game in extensive form. The lender moves first, she decides about the credit application before it is known whether the buyer of the borrower pays or not. The borrower moves next, and chooses about the extent of effort to be exerted. In the third step we treat the exogenous action of the buyer (payment or default) as a move by nature. The last move is by nature again, representing whether the project is successful or not. The elements of the payoff vectors are in the following order. First we get payoff of the project, then the payoff of the borrower, finally the payoff of the lender.

The optimal contract is determined by the individual rationality constraint of the lender and by the incentive compatibility constraint of the borrower as follows. As we note before in case of success the borrower gets $R_{b}$ independently of the action of her buyer and the remaining payoff goes to the lender. Due to Assumption 2.1 the lender will force the borrower to behave. If the borrower behaves, then looking at Figure 2 one finds that the expected payoff of the lender is

$$
p_{H}\left([q+(1-q)(1-c) \delta] R I-[q+(1-q) \delta] R_{b}\right) .
$$

Since we have assumed that the lender lending $I-A$ is risk neutral, she lends on a competitive market and the expected return is zero, the individual rationality constraint of the lender is

$$
p_{H}\left([q+(1-q)(1-c) \delta] R I-[q+(1-q) \delta] R_{b}\right)=I-A .
$$

Using $\alpha=q+(1-q) \delta(1-c)$ defined in Equation (1) we find that the individual rationality constraint of the lender is

$$
p_{H}\left(\alpha R I-\beta R_{b}\right)=I-A,
$$

where for later conveniences $\beta=q+(1-q) \delta$ denotes the expected reduction in the payoff of the borrower $R_{b}$ due to the default risk of the buyer. 


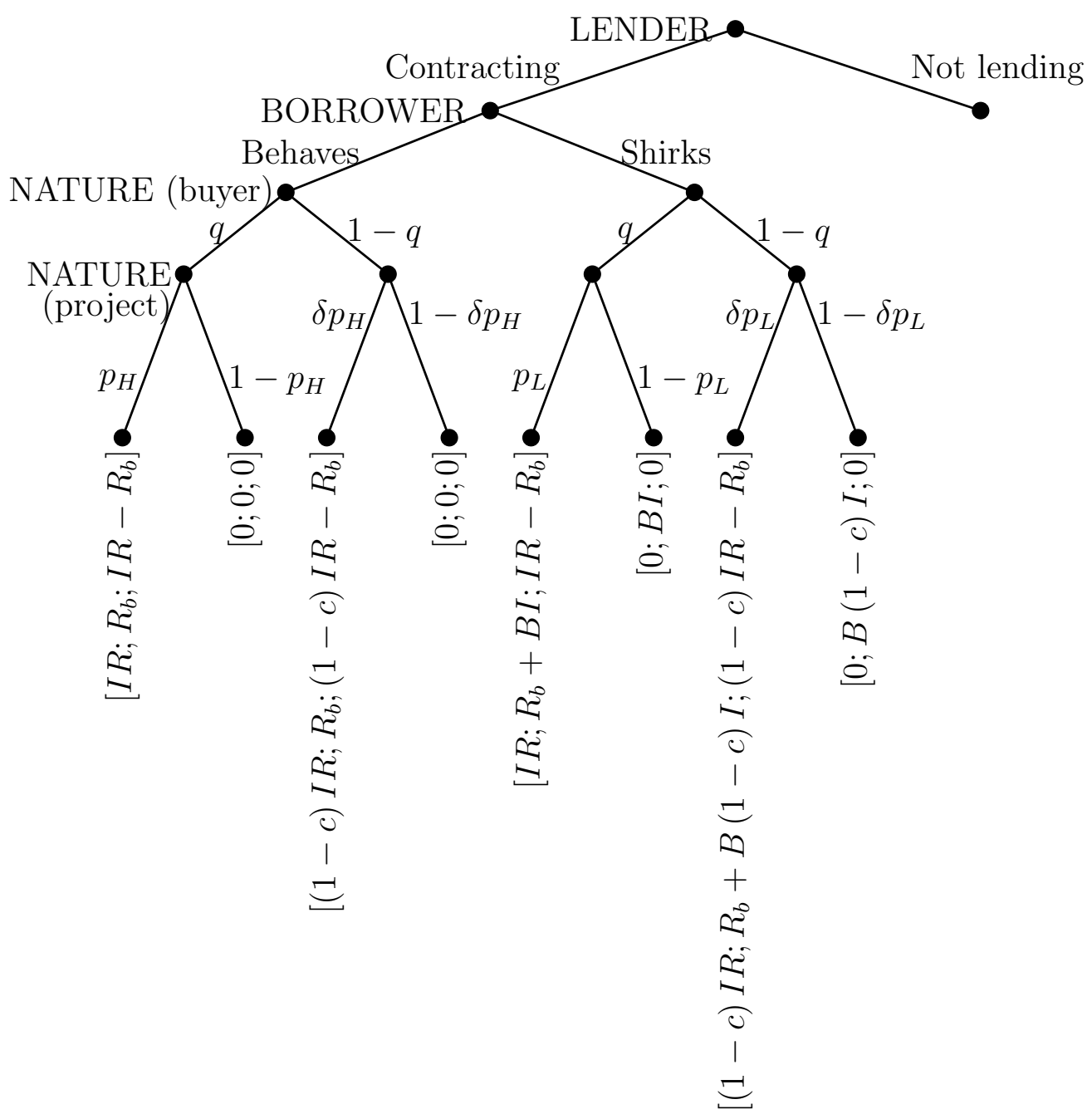

Figure 2: The extensive form of the symmetric game. The payoff vectors are showing the payoff of [the project; the borrower; the lender].

The incentive compatibility constraint of the borrower ensures that her expected payoff attainable through increased efforts is more attractive to her than shirking, even if she considers the private benefits of shirking, that is

$$
\left.\left.p_{H}[q+(1-q) \delta)\right] R_{b} \geq p_{L}[q+(1-q) \delta)\right] R_{b}+[q+(1-q)(1-c)] B I .
$$

Using $\Delta p=p_{H}-p_{L}, \beta$ defined in Equation (5) and $\gamma$ defined in Equation (2) the incentive compatibility constraint of the borrower reads as

$$
R_{b} \geq \frac{B I}{\Delta p} \frac{\gamma}{\beta}
$$

To induce the borrower to behave, this is the minimal payoff that should be offered to her in the debt contract. 
Take any required investment level $I>A$. The question is how much initial cash asset the borrower should have to get the required loan $I-A$.

Proposition 2.2. (Existence of debt contract in the symmetric case)

Take any required investment level $I>A$ in the model of Section 2. In case of symmetric information about the buyer between the lender and the borrower, the lender will give loan $I-A$ to the borrower if

$$
A \geq\left[1-p_{H}\left(\alpha R-\gamma \frac{B}{\Delta p}\right)\right] I=\bar{A}_{s},
$$

where $\bar{A}_{s}$ denotes the lowest initial cash asset required for contracting loan $I-A$.

Proof. After combining Equation (5) with Inequality (7) and expressing $A$ we get Inequality (8).

If the lowest initial cash asset required $\bar{A}_{\mathrm{s}}$ is less than zero, then any investment level can be supported by zero cash, meaning that the equilibrium investment level is infinite. To exclude this case, we assume that the parameters are such that $\bar{A}_{\mathrm{s}}>0$.

Let us use the notation of

$$
k_{\mathrm{s}}=\frac{1}{1-p_{H}\left(\alpha R-\gamma \frac{B}{\Delta p}\right)} .
$$

Inequality (8) can be expressed as

$$
k_{\mathrm{s}} A \geq I .
$$

The borrower can invest $k_{\mathrm{s}}$ times her cash $A$, that is why $k_{\mathrm{s}}$ is called the equity multiplier in the symmetric case. Note that using the inequalities in Assumption 2.1 it follows that

$$
\alpha R>\gamma \frac{B}{\Delta p}
$$

which implies that $k_{\mathrm{s}}>1$, thus there will be a positive amount of loan given to the borrower in the symmetric case. Next, let us discuss the asymmetric case.

\subsection{The asymmetric case}

Figure 3 shows the extensive form of the game in the asymmetric case. First the lender moves and decides about debt contracting. Then nature reveals the exogenous action of the buyer of the borrower. Hence the borrower learns whether her buyer will or will not pay before deciding about behaving or shirking. The last move is by nature again, representing 


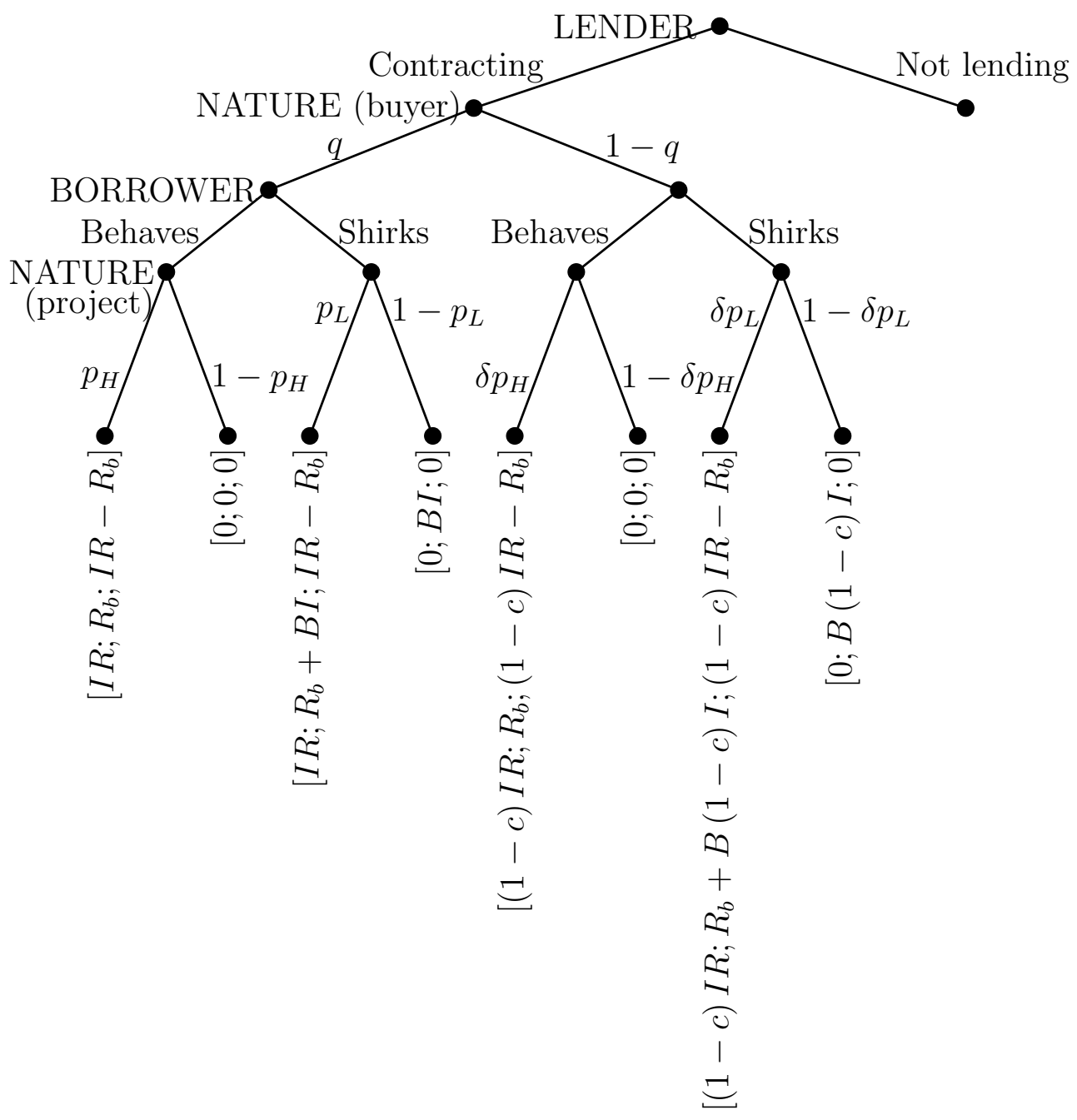

Figure 3: The extensive form of the game with informational advantage of the borrower. The payoff vectors are showing the payoff of [the project; the borrower; the lender]. 
whether the project is successful or not. The elements of the payoff vectors are in the same order as in the symmetric case. First we get payoff of the project, then the payoff of the borrower, finally the payoff of the lender.

Again, the optimal contract is determined by the individual rationality constraint of the lender and by the incentive compatibility constraint of the borrower. Since the lender is risk neutral and also in this case she will induce the borrower to behave, the lender takes the expected value of her payoffs and compares it to the loan $I-A$. Thus similarly as in Equation (5) the individual rationality constraint of the lender is

$$
p_{H}\left(\alpha R I-\beta R_{b}\right)=I-A
$$

The incentive compatibility constraint of the borrower ensures that it is worth for her to behave. However, the borrower knows the action of the buyer when deciding about the level of her efforts. Hence the lender should make sure to induce the borrower to behave independently of the action of her buyer. If the buyer pays, then the incentive compatibility constraint of the borrower is

$$
p_{H} R_{b} \geq p_{L} R_{b}+B I
$$

Using $\Delta p=p_{H}-p_{L}$ Equation (13) can be rearranged as

$$
R_{b} \geq \frac{B I}{\Delta p}
$$

If the buyer is not paying, then the incentive compatible constraints of the borrower becomes

$$
\delta p_{H} R_{b} \geq \delta p_{L} R_{b}+(1-c) B I
$$

which can be rearranged as

$$
\frac{\delta}{1-c} R_{b} \geq \frac{B I}{\Delta p}
$$

If $\delta>1-c$, then Equation (14) is binding. If $\delta<1-c$, then it is Equation (16) which should be considered. We will call $\delta>1-c$ as Case 1 and $\delta \leq 1-c$ as Case 2. The economic interpretations of the two cases are as follows. Case 1 captures industries with low macroeconomic sensitivity and a relatively higher rate of trade credit for supporting buyers. Here the discount factor in success in case of a non-paying buyer $\delta$ is close to one. Case 2 reflects on firms with high macroeconomic sensitivity or firms with a low level of future claims for their buyers. The related equity multipliers are calculated as follows. 
Proposition 2.3. (Existence of debt contract in the asymmetric case)

Take any required investment level I $>A$ in the model of Section 2. In the case of asymmetric information about the buyer between the lender and the borrower, the lender will give loan $I-A$ to the borrower if

$$
A \geq \frac{1}{k_{a}} I=\bar{A}_{a},
$$

where $\bar{A}_{a}$ is the lowest asset level for contracting and the equity multiplier $k_{a}$ is given by

$$
k_{a}= \begin{cases}\frac{1}{1-p_{H}\left(\alpha R-\beta \frac{B}{\Delta p}\right)} & \text { if } \delta>1-c, \\ \frac{1}{1-p_{H}\left(\alpha R-\beta \frac{1-c}{\delta} \frac{B}{\Delta p}\right)} & \text { if } \delta \leq 1-c .\end{cases}
$$

\section{Proof.}

Case $1(\delta>1-c)$ :

The individual rationality constraint of the lender, Equation (12) should be combined with Inequality (14) to get

$$
A \geq I\left\{1-p_{H}\left[\alpha R-\beta \frac{B}{\Delta p}\right]\right\} .
$$

Case $2(\delta \leq 1-c)$ :

Equation (12) and Inequality (16) leads to

$$
A \geq I\left\{1-p_{H}\left[\alpha R-\beta \frac{1-c}{\delta} \frac{B}{\Delta p}\right]\right\} .
$$

Again, we make sure that the equilibrium investment level is finite by assuming that the parameters are such that $\bar{A}_{\mathrm{a}}>0$. Note that Assumption 2.1 does not guarantee that $k_{\mathrm{a}}>1$. In fact we will see in Figure 4 that it can happen that $k_{\mathrm{a}}<1$. In that case there will be no loan given since Equation (17) is not satisfied.

\section{Results}

In this section we analyze the differences between the borrowing capacity in the symmetric and in the asymmetric case and also compare it to the case when the buyer has no default risk. In those cases we also look at the optimal ratio of potential loss due to the buyer $c$. 


\subsection{Equity multipliers}

We have introduced the notion of equity multiplier in order to measure borrowing capacity. For a general equity multiplier $k$, we have that if $k>1$, then the borrower can invest $k$ times her cash asset $A$, implying that she should borrow $(k-1) A$. In terms of conventional financial metrics, $k$ corresponds to the leverage ratio calculated as total assets over equity. The higher the value of $k$, the larger the attainable project size $I$ and the larger the expected net present value (NPV) of the project in Equation (1). The welfare of the project can be measured by the expected NPV. Since there is perfect competition among the lenders, the whole expected NPV goes to the borrower. Thus both the society and the borrower would like to have as high equity multiplier as possible.

To see how the information advantage of the borrower over her buyer is changing borrowing capacity, we have to compare the equity multiplier of the symmetric information case $k_{\mathrm{s}}$ in Equation (9) to the equity multipliers of the asymmetric case $k_{\mathrm{a}}$ in Equation (18).

Proposition 3.1. (The information advantage of the borrower on her buyer weakly reduces borrowing capacity)

The equity multiplier in the symmetric case is at least as large as the equity multiplier in the asymmetric case, $k_{s} \geq k_{a}$.

\section{Proof.}

Case $1(\delta>1-c)$ :

In this case $k_{\mathrm{a}}<k_{\mathrm{s}}$ is equivalent to $1-\frac{1}{k_{\mathrm{a}}}<1-\frac{1}{k_{\mathrm{s}}}$. Using Equations (18) and (9) we have to show that

$$
p_{H}\left(\alpha R-\beta \frac{B}{\Delta p}\right)<p_{H}\left(\alpha R-\gamma \frac{B}{\Delta p}\right),
$$

which has a positive right hand side using Equation (11) and simplifies to

$$
\beta>\gamma
$$

Using $\beta=q+(1-q) \delta$ and $\gamma=q+(1-q)(1-c)$ in Equation (19) we get that $\delta>1-c$, which was our initial assumption.

Case $2(\delta \leq 1-c)$ :

To get that $k_{\mathrm{a}} \leq k_{\mathrm{s}}$ an equivalent inequality is $1-\frac{1}{k_{\mathrm{a}}} \leq 1-\frac{1}{k_{\mathrm{s}}}$. Thus using Equations (18) and (9) we have to show that

$$
p_{H}\left(\alpha R-\beta \frac{1-c}{\delta} \frac{B}{\Delta p}\right) \leq p_{H}\left(\alpha R-\gamma \frac{B}{\Delta p}\right),
$$


which again has a positive right hand side using Equation (11) and can be rearranged as

$$
\beta \frac{1-c}{\delta} \geq \gamma
$$

Expressing $\beta$ and $\gamma$ we get that

$$
q(1-c)+(1-q) \delta(1-c) \geq \delta q+\delta(1-q)(1-c)
$$

which simplifies to our initial assumption $1-c \geq \delta$.

Thus the information advantage of the borrower on her buyer weakly reduces borrowing capacity and hence it also weakly reduces the welfare of both the society and the borrower. It can be considered as an informational paradox, since the information advantage of the borrower hurts herself. However, the solution of the paradox lies in the increased moral hazard. Note that since the symmetric case requires the lowest initial cash for the same investment level $I$, to make sure that the equilibrium investment is finite, it is enough to assume that the parameters are such that $\bar{A}_{\mathrm{s}}>0$.

When the ratio of potential loss due to the buyer $c$ is zero and the discount in success in case of a non-paying buyer $\delta$ is one, then there is no default risk of the buyer. Let us denote the equity multiplier in this case by $k_{0}$ and compare it to the equity multipliers in case the buyer has a nonnegative default risk.

Proposition 3.2. (The default risk of a buyer weakly decreases borrowing capacity) If the buyer has no default risk, that is $c=0$ and $\delta=1$, then the equity multiplier is at least as large as if the buyer has default risk, $k_{0} \geq k_{s}$ and $k_{0} \geq k_{a}$.

Proof. By Proposition 3.1 if the buyer has default risk, then the largest possible multiplier is in the symmetric case and by Equation (9) it is given as

$$
k_{\mathrm{s}}=\frac{1}{1-p_{H}\left(\alpha R-\gamma \frac{B}{\Delta p}\right)} .
$$

We have to compare it to the case when the buyer has no default risk. Using $c=0$ and $\delta=1$ in $\alpha=q+(1-q) \delta(1-c)$ and $\gamma=q+(1-q)(1-c)$ we get that $\alpha=1$ and $\gamma=1$, thus the equity multiplier if the buyer has no default risk is given as

$$
k_{0}=\frac{1}{1-p_{H}\left(R-\frac{B}{\Delta p}\right)} .
$$

If $c \geq 0$, then we have that $\alpha \leq \gamma \leq 1$, which using Equation (11) implies that 


$$
\begin{aligned}
k_{\mathrm{s}} & =\frac{1}{1-p_{H}\left(\alpha R-\gamma \frac{B}{\Delta p}\right)} \leq \frac{1}{1-p_{H}\left(\gamma R-\gamma \frac{B}{\Delta p}\right)} \leq \\
& \leq \frac{1}{1-p_{H}\left(R-\frac{B}{\Delta p}\right)}=k_{0} .
\end{aligned}
$$

Thus we have proven that the default risk of a buyer weakly decreases borrowing capacity, and hence it also weakly decreases the welfare of both the society and the borrower. It seems that if it can be chosen by the borrower, then the optimal ratio of potential loss due to the buyer $c$ should be zero. However, as the next subsection shows, it is not always the case.

\subsection{The optimal ratio of potential loss due to the buyer $c$}

Let us assume that a borrower can choose the ratio of potential loss due to the buyer $c$ to maximize her welfare. Since the welfare of the borrower and the size of the equity multiplier move together, the borrower would like to maximize the equity multiplier. Let us analyze how it can be done both in the symmetric and in the asymmetric case. We assume that the buyer is not paying for sure $(q<1)$, otherwise modifying $c$ would have no effect.

Before doing that, note that Assumption 2.1 constraints the possible values of $c$ as follows. To have a positive NPV when behaving, $c$ must not be too high, that is

$$
c<1-\frac{1-q p_{H} R}{(1-q) p_{H} R \delta}=\bar{c}
$$

should be satisfied. To have a negative NPV when shirking, $c$ must not be too low, that is

$$
c>1-\frac{1-q\left(p_{L} R+B\right)}{(1-q)\left(\delta p_{L} R+B\right)}=\underline{c}
$$

should hold. Thus $c \in[\underline{c}, \bar{c}] \cap[0,1]=\left[c_{\min }, c_{\max }\right]$, where using Equations (21) and (22) we get that

$$
c_{\min }= \begin{cases}0 & \text { if } q \leq 1-\frac{1-\left(p_{L} R \delta+B\right)}{(1-\delta) p_{L} R} \\ \underline{c} & \text { if } q>1-\frac{1-\left(p_{L} R \delta+B\right)}{(1-\delta) p_{L} R}\end{cases}
$$

and

$$
c_{\max }= \begin{cases}\bar{c} & \text { if } q \leq \frac{1}{p_{H} R}, \\ 1 & \text { if } q>\frac{1}{p_{H} R} .\end{cases}
$$


Proposition 3.3. (The optimal ratio of potential loss due to the buyer c)

Assume that the buyer is not paying for sure, $q<1$. Let $\delta^{*}=\frac{B}{\Delta p} \frac{1}{R}$. In the symmetric case the equity multiplier $k_{s}$ reaches its maximum

a) at $c=c_{\min }$ (when the buyer has no default risk) if $\delta>\delta^{*}$;

b) at $c=c_{\max }$ if $\delta<\delta^{*}$; and

c) it is constant and maximal everywhere if $\delta=\delta^{*}$.

Let

$$
q^{*}=\frac{\delta R-\frac{B}{\Delta p}}{\delta R-\frac{B}{\Delta p}\left(1-\frac{1}{\delta}\right)} .
$$

In the asymmetric case the equity multiplier $k_{a}$ reaches its maximum

a) at $c=c_{\min }$ if $q<q^{*}$;

b) at $c=c_{\min }$ if $q \geq q^{*}$ and $c_{\min } \geq 1-\delta$;

c) at $c=c_{\max }$ if $q>q^{*}$ and $c_{\max }<1-\delta$;

d) at $c=1-\delta$ if $q>q^{*}$ and $c_{\min }<1-\delta<c_{\max }$; and

e) it is constant and maximal everywhere in $c \in\left[0, \min \left\{c_{\max }, 1-\delta\right\}\right]$ if $q=q^{*}$ and $c_{\min }<1-\delta$.

\section{Proof.}

In the symmetric case the equity multiplier $k_{\mathrm{s}}$ given by Equation (9) has the partial derivative

$$
\frac{\partial k_{\mathrm{s}}}{\partial c}=-\frac{p_{H}(1-q)\left[\delta R-\frac{B}{\Delta p}\right]}{\left(1-p_{H}\left(\alpha R-\gamma \frac{B}{\Delta p}\right)\right)^{2}} .
$$

If $\delta>\frac{B}{\Delta p} \frac{1}{R}=\delta^{*}$, then since $p_{H}>0$ and $q<1$ we have that $\frac{\partial k_{\mathrm{s}}}{\partial c}<0$, thus the maximum of $k_{\mathrm{s}}$ is at $c=c_{\min }$.

If $\delta<\delta^{*}$, then since $p_{H}>0$ and $q<1$ we have that $\frac{\partial k_{\mathrm{s}}}{\partial c}>0$, thus the maximum of $k_{\mathrm{s}}$ is at $c=c_{\max }$.

If $\delta=\delta^{*}$, then $\frac{\partial k_{\mathrm{s}}}{\partial c}=0$.

Next, let us analyze the asymmetric case. If $\delta>1-c$, that is $c>1-\delta$, then $k_{\mathrm{a}}$ given by Equation (18) is a monotone decreasing function of $c$, since by assumption $p_{H}>0$, $q<1$ and

$$
\frac{\partial k_{\mathrm{a}}}{\partial c}=-\delta(1-q) p_{H} R k_{\mathrm{a}}^{2}<0 .
$$


Thus the maximum of $k_{\mathrm{a}}$ for $c \in[1-\delta, 1]$ is at $c=1-\delta$.

If $\delta \leq 1-c$ that is $c \leq 1-\delta$, then $k_{\mathrm{a}}$ can move in any direction in $c$, since by assumption $p_{H}>0, q<1$ and

$$
\frac{\partial k_{\mathrm{a}}}{\partial c}=-p_{H}\left(\delta(1-q) R-\frac{1}{\delta} \beta \frac{B}{\Delta p}\right) k_{\mathrm{a}}^{2} .
$$

Looking at the expression after $p_{H}$ in brackets in Equation (28) let us define the threshold $q^{*}$ as

$$
q^{*}=\frac{\delta R-\frac{B}{\Delta p}}{\delta R-\frac{B}{\Delta p}\left(1-\frac{1}{\delta}\right)} .
$$

If $q<q^{*}$, then for $c \leq 1-\delta$ we have that $\frac{\partial k_{\mathrm{a}}}{\partial c}<0$, thus the maximum of $k_{\mathrm{a}}$ is at $c=c_{\min }$ in part a).

For $c \leq 1-\delta$ if $q>q^{*}$, then we have that $\frac{\partial k_{\mathrm{a}}}{\partial c}>0$, if $q=q^{*}$, then we have that $\frac{\partial k_{\mathrm{a}}}{\partial c}=0$ - Depending on the relationships among $c_{\min }, c_{\max }$ and $1-\delta$ parts b), c), d) and e) are explained.
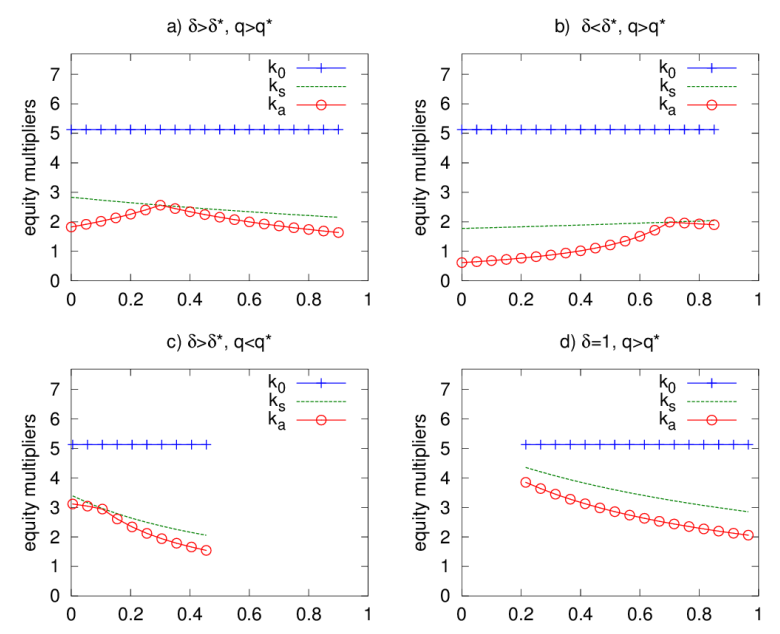

Figure 4: The equity multipliers as a function of the ratio of potential loss due to the buyer $(c)$ in case the buyer has no default risk $\left(k_{0}\right)$, in the symmetric case $\left(k_{\mathrm{s}}\right)$ and in the asymmetric case $\left(k_{\mathrm{a}}\right)$.

Panels a), b), c) and d) of Figure 4 illustrate Propositions 3.2, 3.1 and 3.3. Depending on the relationship between $\delta$ and $\delta^{*}$ and $q$ and $q^{*}$ we might have four cases, but as it can be easily verified $\delta<\delta^{*}$ and $q<q^{*}$ cannot happen at the same time, thus panel d) contains 


\begin{tabular}{c|cccccc|cccc} 
& $p_{H}$ & $p_{L}$ & $R$ & $B$ & $\delta$ & $q$ & $\delta^{*}$ & $q^{*}$ & $c_{\min }$ & $c_{\max }$ \\
\hline $\mathrm{a})$ & 0.7 & 0.3 & 2.15 & 0.4 & 0.7 & 0.65 & 0.4651 & 0.2612 & 0 & 0.9410 \\
$\mathrm{~b})$ & 0.7 & 0.3 & 2.15 & 0.4 & 0.3 & 0.65 & 0.4651 & -0.1192 & 0 & 0.8624 \\
$\mathrm{c})$ & 0.7 & 0.3 & 2.15 & 0.4 & 0.9 & 0.35 & 0.4651 & 0.4569 & 0.0048 & 0.4625 \\
$\mathrm{~d})$ & 0.7 & 0.3 & 2.15 & 0.4 & 1.0 & 0.80 & 0.4651 & 0.5348 & 0.2153 & 1
\end{tabular}

Table 1: The parameters used in Figure 4.

an other interesting case with $\delta=1$. Just like Proposition 3.2 claims in general, the equity multiplier if the buyer has no default risk $\left(k_{0}\right)$ is the largest on all panels, and since it does not depend on $c$, it is constant. In accordance with Proposition 3.1, the second largest equity multiplier is in the symmetric case $\left(k_{\mathrm{s}}\right)$ and by Proposition 3.1 the equity multiplier in the asymmetric case $\left(k_{\mathrm{a}}\right)$ is at most as large as in the symmetric case $\left(k_{\mathrm{s}}\right)$ on all panels. Note that $k_{\mathrm{a}}<1$ for a while on panel b). In that case there will be no loan given since Equation (17) is not satisfied.

Proposition 3.3 allows both $k_{\mathrm{s}}$ and $k_{\mathrm{a}}$ to be maximal at $c=c_{\min }$, this can be seen on panels c) and d). However, on panel b) both $k_{\mathrm{s}}$ and the first part of $k_{\mathrm{a}}$ are increasing, they are maximal somewhere in the middle $\left(k_{\mathrm{s}}\right.$ at $c=c_{\max }=0.86245$ and $k_{\mathrm{a}}$ at $\left.c=1-\delta=0.7\right)$. This means that in those cases the borrower has to have a risky buyer to boost borrowing capacity and her welfare. The intuitive explanation is the following. Increasing $c$ has two effects. On the one hand using $\alpha=q+(1-q) \delta(1-c)$ defined in Equation (1) it is increasing the expected discount to the payoff of the project $R I$ due to the default risk of the buyer, which decreases the welfare of the borrower. On the other hand looking at $\gamma=q+(1-q)(1-c)$ defined in Equation (2) it is increasing the expected reduction in the value of the private benefit of the project $B I$ due to the default risk of the buyer, leading to a lower moral hazard in lending. On panel a) the latter effect dominates only in the asymmetric case up to $c=1-\delta=0.3$. Note that on panels a), b) and c) the maximal possible value of $c$ is less than one and on panels c) and d) the minimal value of $c$ is larger than zero.

\section{Conclusion}

We have presented a model of corporate financing where the borrower may have informational advantage about the default of her risky buyers. On top of whether the borrower behaves or shirks, the risky buyers generate additional asymmetric information between the borrower and the lender. We have shown how the lender modifies the offered credit terms depending on if the borrower knows (asymmetric case) or does not know (symmetric 
case) whether her buyers will pay in the future before she can substantially modify her efforts. It turned out that the higher the borrowing capacity the higher the welfare of both the society and the borrower.

The asymmetric case is typical in Small and Medium Sized Enterprises, where the borrower and her buyers are socially interconnected. In this case there is a high chance that the borrower becomes aware of the financial difficulties of her buyers. To avoid the shirking actions of the borrower, the lender must offer a special debt contract. We have found that the borrower accesses only a weakly lower level of external financing if she had an information advantage on her buyers. This unwanted practice cannot be eliminated by only providing more liquidity for firms.

As it was expected, we have shown that the nonnegative default risk of a buyer weakly decreases borrowing capacity compared to the case when the buyer pays for sure. We have also calculated how the borrower should set the ratio of potential loss due to the buyer. The optimal value of claims on risky buyers can be zero or a positive number both in the asymmetric and in the symmetric case. Thus the welfare of the borrower may be increased by lending to a risky buyer. In this case the higher trade credit is not increasing sales in the model, but reduces the private benefit of shirking more than the expected payoff of the project.

\section{References}

Beck T, Demirguc-Kunt A, Peria MSM (2007) Reaching out: Access to and use of banking services across countries. Journal of Financial Economics 85(1):234-266

Biais B, Gollier C (1997) Trade Credit and Credit Rationing. Review of Financial Studies 10(4):903-37

Brennan MJ, Maksimovic V, Zechner J (1988) Vendor Financing. Journal of Finance 43(5):1127-41

Carbó-Valverde S, Rodríguez-Fernández F, Udell GF (2008) Bank lending, financing constraints and SME investment. Working Paper Series WP-08-04, Federal Reserve Bank of Chicago

Cook LD (1999) Trade credit and bank finance: Financing small firms in russia. Journal of Business Venturing 14(5-6):493-518

Demirguc-Kunt A, Maksimovic V (2001) Firms as financial intermediaries - evidence from trade credit data. Policy Research Working Paper Series 2696, The World Bank 
Devjak S, Bogataj L (2007) Optimisation of short term commercial bank loans to corporates in terms of financing operating activities in Slovenia. Central European Journal of Operations Research 15(4):393-403

Emery GW (1984) A Pure Financial Explanation for Trade Credit. Journal of Financial and Quantitative Analysis 19(03):271-285

Fudenberg D, Tirole J (1990) Moral Hazard and Renegotiation in Agency Contracts. Econometrica 58(6):1279-1319

Garcia-Appendini E (2007) Soft Information in Small Business Lending . EFA 2007 Ljubljana Meetings Paper

Garcia-Appendini E, Montoriol-Garriga J (2012) Firms as liquidity providers: Evidence from the 2007-2008 financial crisis . Journal of Financial Economics Forthcoming

Hart O, Moore J (1998) Default And Renegotiation: A Dynamic Model Of Debt. The Quarterly Journal of Economics 113(1):1-41

Holmstrom B, Tirole J (2000) Liquidity and Risk Management. Journal of Money, Credit and Banking 32(3):295-319

Klingen C, Castillo L (2012) European Banking Coordination "Vienna" Initiative. Tech. rep.

Myers SC (1977) Determinants of corporate borrowing. Journal of Financial Economics $5(2): 147-175$

Petersen M, Rajan R (1994) The benefits of lending relationships: Evidence from small business data. The Journal of Finance 49(1):3-37

Raddatz C (2010) Credit Chains and Sectoral Comovement: Does the Use of Trade Credit Amplify Sectoral Shocks? The Review of Economics and Statistics 92(4):985-1003

Schwartz RA (1974) An Economic Model of Trade Credit. Journal of Financial and Quantitative Analysis 9(04):643-657

Tirole J (2006) The theory of corporate finance. Princeton University Press, Princeton, N.J. 